\title{
Article \\ Thermal Behavior of a BIPV Combined with Water Storage: An Experimental Analysis
}

\author{
José Marco Lourenço *, Laura Aelenei (D), Miguel Sousa, Jorge Facão *(D) and Helder Gonçalves \\ Laboratório Nacional de Energia e Geologia (LNEG), 1649-038 Lisboa, Portugal; laura.aelenei@lneg.pt (L.A.); \\ miguel.el.sousa@gmail.com (M.S.); helder.goncalves@lneg.pt (H.G.) \\ * Correspondence: jose.lourenco@lneg.pt (J.M.L.); jorge.facao@lneg.pt (J.F.); \\ Tel.: +351-21-092-4600 (ext. 4342) (J.M.L.)
}

check for updates

Citation: Lourenço, J.M.; Aelenei, L.; Sousa, M.; Facão, J.; Gonçalves, H. Thermal Behavior of a BIPV Combined with Water Storage: An Experimental Analysis. Energies 2021, 14, 2545. https://doi.org/10.3390/ en14092545

Academic Editor: Jorge de Brito

Received: 28 February 2021

Accepted: 27 April 2021

Published: 29 April 2021

Publisher's Note: MDPI stays neutral with regard to jurisdictional claims in published maps and institutional affiliations.

Copyright: (c) 2021 by the authors. Licensee MDPI, Basel, Switzerland. This article is an open access article distributed under the terms and conditions of the Creative Commons Attribution (CC BY) license (https:// creativecommons.org/licenses/by/ $4.0 /)$.

\begin{abstract}
Buildings play an active role in the global energy consumption and are required to not only minimize their energy use, but also generate energy in a sustainable manner. The integration of renewable energies in building elements can improve their overall performance, as they are able to replace common construction materials, while offering both electrical and thermal energy. The scope of this paper is to present the first results of an experimental study of a Building-Integrated Photovoltaic system combined with a water storage tank (BIPV-WS), a combined integration not extensively studied yet. Both layers are separated by a ventilated air cavity, and the thermal behavior of the system was analyzed experimentally in real functioning conditions. The water tank performs as a thermal storage, maintaining a regular temperature of about $20-30{ }^{\circ} \mathrm{C}$ during a typical winter day of Lisbon for a period of $11 \mathrm{~h}$. Moreover, through the ventilation of the air cavity, the heat provided by the solar panel was naturally recovered to the indoors of the building, while keeping the temperature high enough to heat up the water. During summer, the ventilated BIPV-WS enabled beneficial nocturnal heat loss while delaying diurnal space heating.
\end{abstract}

Keywords: water storage; nZEB; integrated façades; building-integrated photovoltaic system; buildings

\section{Introduction}

Current studies and political trends on climate change made it imperative to reduce the human dependency on conventional energy source emitters of greenhouse gases (GHG). Designing energy efficient and affordable integrated solutions for buildings that deal with summer and winter climate challenges represents a very ambitious target. Moreover, the increasing energy consumption, shrinking resources, and rising energy costs have a significant impact on the standard of living for future generations. In this situation, the development and adoption of alternative renewable energy systems and technologies integrated in residential and non-residential buildings have to be a priority. In addition to this, with the publication of the recast of the Energy Performance of Buildings Directive in May 2010, Zero Energy performance targets for all buildings were set [1]. The integration of solar energy systems into buildings becomes imperative in this context. As is well known, a Zero Energy Building design does not only mean the adoption of energy efficiency measures, but also the integration of renewable energy systems in order to balance the building energy consumption [2]. The advantages of photovoltaic (PV) systems integration in buildings envelope are numerous, resulting in a growing interest of these technologies in building design and construction from electricity generation solutions to offset building demands, building materials, and components [3-5].

Approximately $16 \%$ of the solar energy incident on PV systems is successfully converted to electricity, while the remainder is absorbed and transformed into heat [6,7]. Thus, integrating photovoltaic systems in façades enables not only electricity generation, but also the ability to make use of the generated heat [8-10]. 
Numerical studies have been performed that corroborate the role of the additional heat provided by building-integrated photovoltaic systems in increasing occupants thermal comfort [11,12]. In addition, experimental studies also have been performed to prove the benefits of the building-integrated photovoltaic systems [13-15]. Combining solar energy building-integrated system with thermal storage, such as when using phase-change materials, was also found to be an effective solution for reducing peak loads and controlling associated temperature fluctuations $[3,16]$.

Efficiencies of this kind of system were often calculated to better understand the thermal behavior and efficiency of the overall system and also the electric efficiency of the PV-integrated panel. Agrawal and Tiwari [7] evaluated a rooftop-integrated photovoltaic thermal system for diverse configurations, making use of the heat generated by the PVs to maintain a higher room temperature and assist space heating. Additionally, the authors of [17] validated and simulated a building-integrated photovoltaic (BIPV) Trombe wall system, achieving improved electrical and thermal efficiencies of $4.5 \%$ and $27.2 \%$, respectively. Charron and Athienitis [18] analyzed the BIPV combined thermal-electric efficiency for diverse configurations, attaining efficiencies of over $55 \%$ for finned BIPVs, presenting an increase of $80 \%$ when compared to a BIPV configuration with airflow on one side of the PV without fins (30\%), similar to the data provided in [17]. The presented finned BIPV configuration [18] would attain similar thermal-electric results as BIPVs with airflow on both sides, favoring electricity production over further increased heat retention. Pereira [19] studied the performance of a similar BIPV with thermal storage properties using PCM (BIPV-PCM) through a MATLAB/SIMULINK thermal network, attaining about $10 \%$ thermal efficiency and $20 \%$ overall efficiency.

By choosing high thermal capacity materials, sensible heat storage allows the heat to be stored with minimal increase in temperature. While, for example, concrete elements do present these advantages, water possesses higher thermal capacity and has been the subject of study for both wall and roof components, proving to be an effective and economical solution that can improve the indoor thermal comfort while reducing energy demand and usage of concrete of the building [20]. As such, sensible heat storage through a water tank can provide control of the associated temperature fluctuation through the whole integrated system while presenting lower initial capital cost when compared with innovative materials such as PCM.

This paper presents the first experimental investigation of a Building-Integrated Photovoltaics combined with a water storage tank (BIPV-WS) as part of a façade of the Solar Building XXI. The experiment is part of the current research project NZEB_LAB, of which the aim is to promote testing and development of all the applications of solar energy in buildings, with this work being part of the Research Activity 2.1 "Experimental investigation of new applications, solar energy innovative systems (laboratory and real building), and building and integrated solar systems energy flexibility."

This study is focused on two research outcomes: the improvement of the indoor thermal comfort, the reduction of the energy demands, and the improvement of the efficiency of the photovoltaic system by limiting the temperature rise inside the system. These two objectives can be achieved by ventilating the air cavity behind the PV module (BIPV). The heat released in the conversion process from PV can be successfully recovered and used for indoor heating through natural ventilation during the heating period or evacuated to the exterior and avoid overheating during the cooling period. On the other hand, the integration of a water tank is used for leveling the indoor and outdoor temperature difference and the rapid stabilization of PV modules' temperature, which in turn improves PV solar energy conversion efficiency $[17-19,21]$. The design of such a system is a complex task that requires a detailed investigation of the heat and mass transfer phenomena related to the prefabricated module.

This paper addresses the preliminary investigation phase of this system, which consists in the first experimental results obtained. 


\section{Case Study and Experimental Design Description}

Designing, developing and testing new solutions of façade integrated elements is one of the main objectives of the research activities integrated in the framework of NZEB_LAB Research Infrastructure on Solar Energy Systems, located in Lisbon, Portugal [22]. This research infrastructure, financed by the National Laboratory of Energy and Geology (LNEG), integrates experimental capacities and equipment in the area of solar systems (Solar Energy Laboratory) and materials (Laboratory of Material and Coatings) and the Solar XXI building — a Nearly Zero Energy Building (NZEB) office facility—functions as a living lab and is used to test solutions for building façades in a real environment.

\subsection{Solar XXI Building}

The Solar XXI building is one of the main testing platforms of the NZEB_LAB infrastructure, where building façade prototypes can be installed and tested in a real environment (Figure 1).

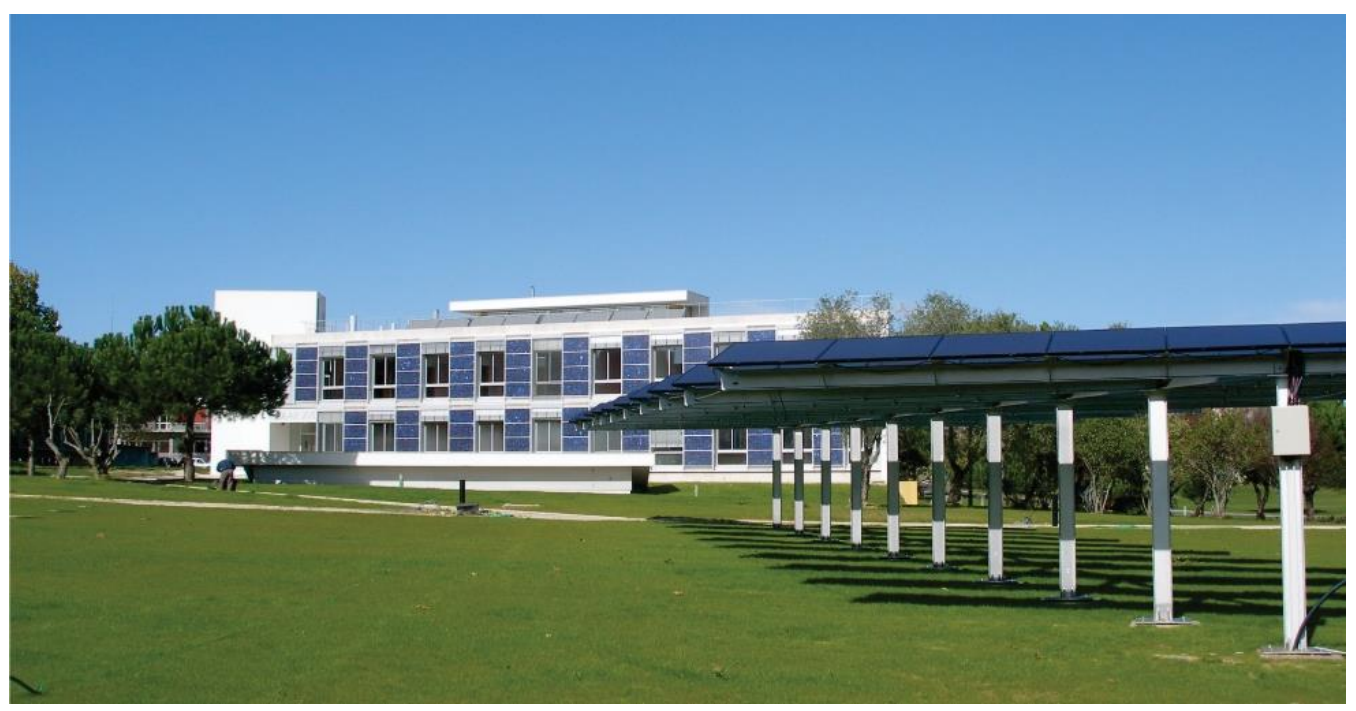

Figure 1. Solar XXI building.

Solar XXI was built in Lisbon in 2006 as a demonstration project [23] of the National Laboratory of Energy and Geology (LNEG), with the objective to be an example of a solar, low-energy building using passive systems both for heating and cooling (ground cooling) towards an NZEB $[13,24]$. The building integrates several passive solutions for energy demand reduction in winter and summer. The main façade is south oriented and has a BIPV system $10 \mathrm{~cm}$ away from the masonry wall [14], allowing air circulation and providing heat recovery into the indoor space, which assists the heating in wintertime. In summer, a ground cooling system (earth tubes) is used to cool the building, together with the solar protection through Venetian blinds and night cooling strategies through the ventilation with building openings, including a central skylight [25].

The BIPV system consists of 76 multi-crystalline silicone modules that have an area of about $96 \mathrm{~m}^{2}$ with $12 \mathrm{~kW}$ peak power installed [25]. Productivity is about $1004 \mathrm{kWh} / \mathrm{kW}$ [24,25]. Although the building is an office building, on the ground floor, two test rooms (Figure $2 b$ ) are prepared for integrating and testing façade prototypes. 


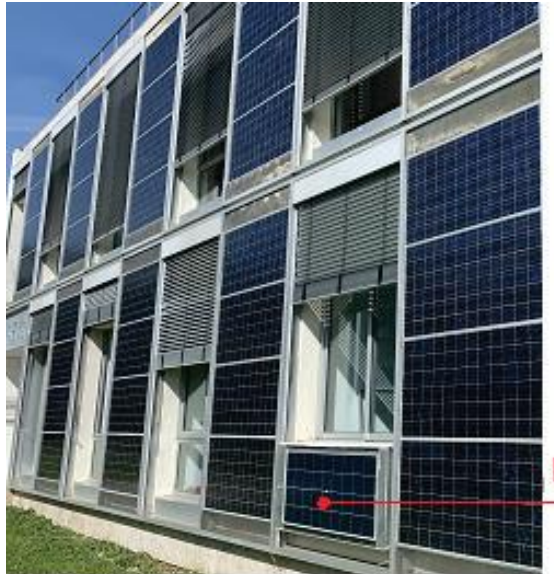

(a)

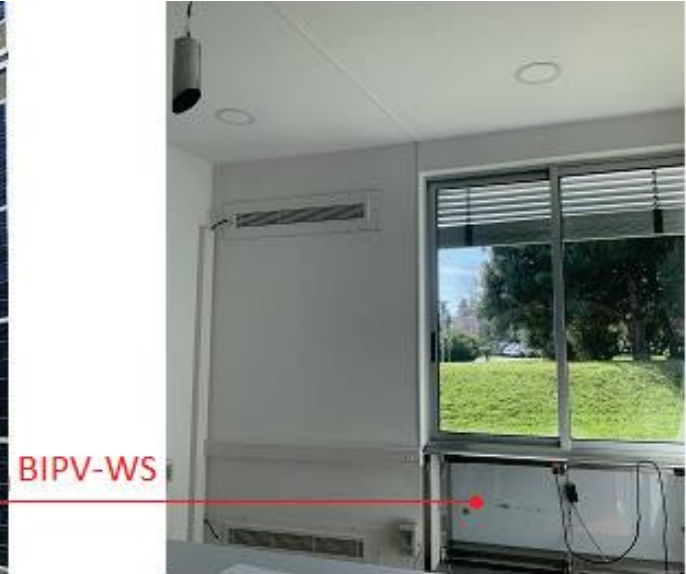

(b)

Figure 2. Prototype integrated in the façade [15]: (a) outside view; (b) inside view-test room.

\subsection{BIPV-WS Prototype Description}

The BIPV-WS prototype was installed on a main façade of Solar XXI in late winter 2019 , and since then, has been tested in real conditions. The modules consist of an outer layer (Atersa ESPMC150 PV panel [26]) and an inner layer (water tank), separated by an air cavity which can be ventilated. As previously mentioned, these systems should be designed to operate according to the needs of the building and the climate conditions.

During the daytime in the heating season, the heat converted by the PV panels was naturally recovered through the air cavity, through natural ventilation, and conducted to the adjacent space through the internal vents (Figure 3). During the nighttime, the ventilation vents were closed, and the heat stored in the water tanks allowed to keep the indoor space temperature warm (over $20^{\circ} \mathrm{C}$ ) and prevent heat losses.

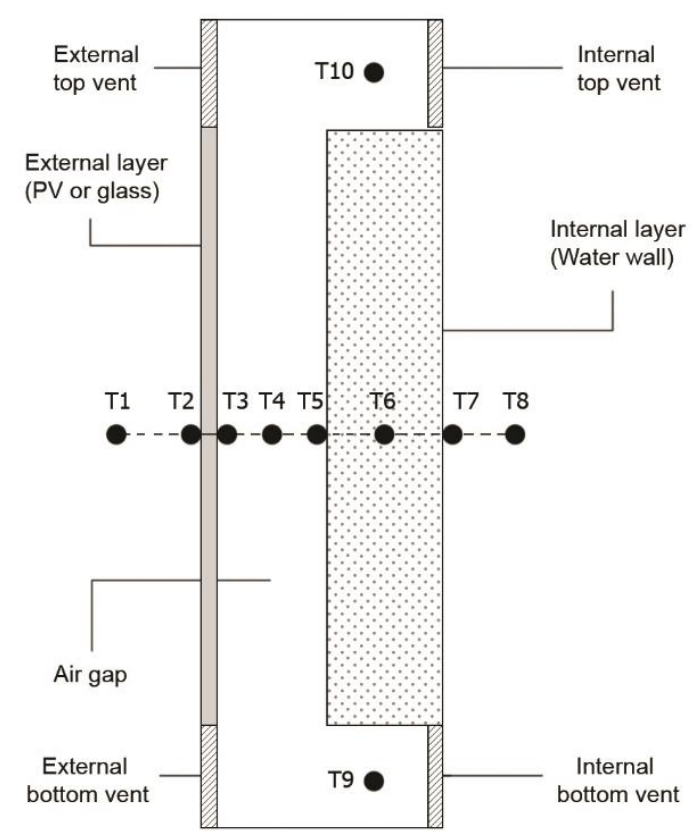

Figure 3. BIPV-WS prototype configuration [15].

In the summer, the system operates by ventilating the air cavity through the exterior vents (Figure 3) to release the heat accumulated and prevent overheating.

The main characteristics of the prototype are described in Table 1. 
Table 1. Properties of the prototype components.

\begin{tabular}{cc}
\hline System Layer & Properties \\
\hline PV & $\begin{array}{c}\text { The PV polycrystalline module has a peak power, } \mathrm{P}_{\text {max }} \text { of about } \\
150\left(\mathrm{~W}_{\mathrm{P}}\right), \text { a Short Circuit Current }\left(\mathrm{I}_{\mathrm{SC}}\right) \text { of } 8.69(\mathrm{~A}), \text { and an Open Circuit } \\
\text { Voltage }\left(\mathrm{V}_{\mathrm{OC}}\right) \text { of } 22.7(\mathrm{~V}) .\end{array}$ \\
\hline Air cavity & $\begin{array}{r}\text { The air cavity cross section has a rectangular shape with } 1.75 \mathrm{~m} \text { width } \\
\text { and } 0.1 \mathrm{~m} \text { depth, and the cavity has a height of } 0.66 \mathrm{~m} .\end{array}$ \\
\hline Water tank & $\begin{array}{r}\text { Water tank of } 1.50 \mathrm{~m} \text { of width and height of } 0.54 \mathrm{~m}(60 \mathrm{~L}) \mathrm{with} \text { compact } \\
\text { polycarbonate walls of } 0.01 \mathrm{~m} \text { thickness }(\mathrm{k}=0.2 \mathrm{~W} / \mathrm{mK}[27]) .\end{array}$ \\
\hline
\end{tabular}

\subsection{Experimental Setup}

The BIPV-WS prototype is completely monitored on all surfaces and in the inner air cavity in order to understand the thermal behavior of the system. Interior and exterior air temperatures are also monitored as well as the solar global radiation using a weather station installed on the roof of Solar XXI (Figure 4).

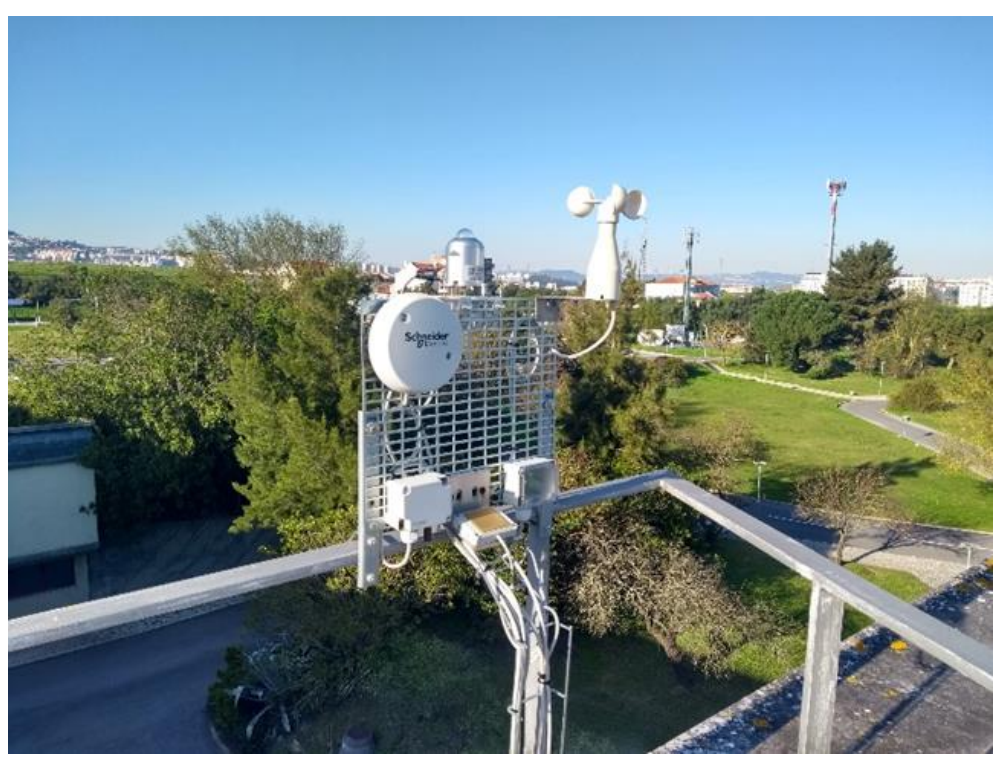

Figure 4. Weather station on the roof of Solar XXI.

For the assessment of the thermal behavior of the prototypes, PT100 $2 \times 2.3 \mathrm{~mm}$ sensors of class B were placed in each layer of the prototype, which measure the average temperature in 10-min intervals. Three different type of sensors were used, depending on their application, and with characteristics displayed in Table 2.

Table 2. Applied sensors.

\begin{tabular}{ccc}
\hline Sensor & Application & Temperature Range $\left({ }^{\circ} \mathrm{C}\right)$ \\
\hline $\begin{array}{c}\text { Omega } \\
\text { PR-10-2-M45-100-ST }\end{array}$ & Surface & {$[-50,200]$} \\
\hline $\begin{array}{c}\text { Omega } \\
\text { SA2F-RTD-3-100-A-10M }\end{array}$ & Emersion and Air & {$[-200,600]$} \\
\hline RS Pro & Environment & {$[-10,40]$} \\
\hline 376-1477 & & \\
\hline
\end{tabular}


Together with the PT100 thermometer, which displays an uncertainty of $\pm 0.05^{\circ} \mathrm{C}$, the total tolerance of these sensors increases linearly with the temperature, according to the following Equation (1):

$$
\Delta \mathrm{T}= \pm(0.35+(5 \times \mathrm{T}) / 1000), \text { for } \mathrm{T} \in[0,100]^{\circ} \mathrm{C},
$$

Following the equation, in a scenario where the PV surface temperature is $60{ }^{\circ} \mathrm{C}$, the maximum error will be $\pm 0.65{ }^{\circ} \mathrm{C}$, which proves the accuracy of the sensors for an experimental study.

The distribution of the sensors throughout the internal layers can be represented by their cross-section, as shown in Figure 3, together with the nomenclature provided in Table 3.

Table 3. Nomenclature of the experimental setup (temperature sensors).

\begin{tabular}{ccc}
\hline Sensor & Position & Temperature \\
\hline T1 & Exterior environment & $\mathrm{T}_{\text {ext }}$ \\
T2 & PV external surface & $\mathrm{T}_{\mathrm{PV} \text {,ext }}$ \\
$\mathrm{T} 3$ & PV internal surface & $\mathrm{T}_{\mathrm{PV} \text {,int }}$ \\
$\mathrm{T} 4$ & Air cavity & $\mathrm{T}_{\text {air }}$ \\
$\mathrm{T} 5$ & Water tank internal surface & $\mathrm{T}_{\mathrm{wt} \text {,int }}$ \\
$\mathrm{T} 6$ & Water tank & $\mathrm{T}_{\mathrm{water}}$ \\
$\mathrm{T} 7$ & Water tank external surface & $\mathrm{T}_{\mathrm{wt} \text {,ext }}$ \\
$\mathrm{T} 8$ & Interior environment & $\mathrm{T}_{\text {int }}$ \\
T9 & Air cavity top & $\mathrm{T}_{\text {air,top }}$ \\
T10 & Air cavity bottom & $\mathrm{T}_{\text {air,bot }}$ \\
\hline
\end{tabular}

\section{Experimental Analysis and Results}

\subsection{Weather Analysis and Experimental Campaign}

The BIPV-WS was tested during the winter and summer seasons. Figure 5 and Table 4 present the measured indoor and outdoor environmental conditions during the months of February and August 2020, where Tint is the measured interior temperature of the test room, and Text and Radiation are the exterior temperature and global horizontal radiation measured by the weather station in Figure 4, respectively. Further data on the local environmental conditions throughout 2020 are presented in Appendix A.

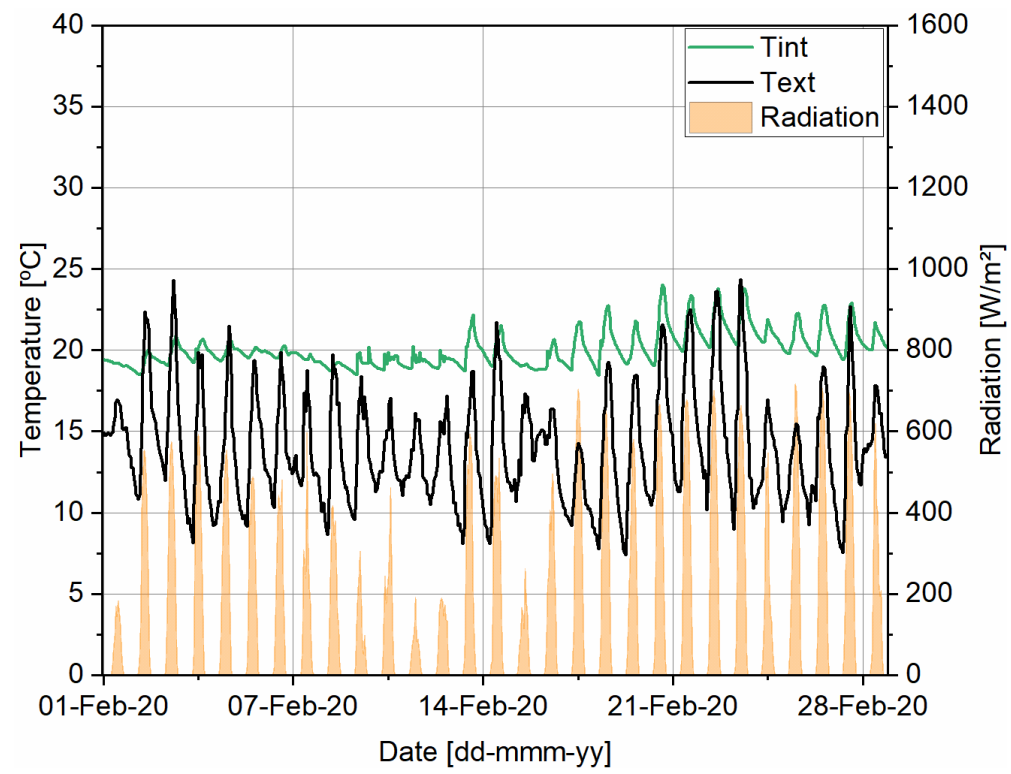

(a)

Figure 5. Cont. 


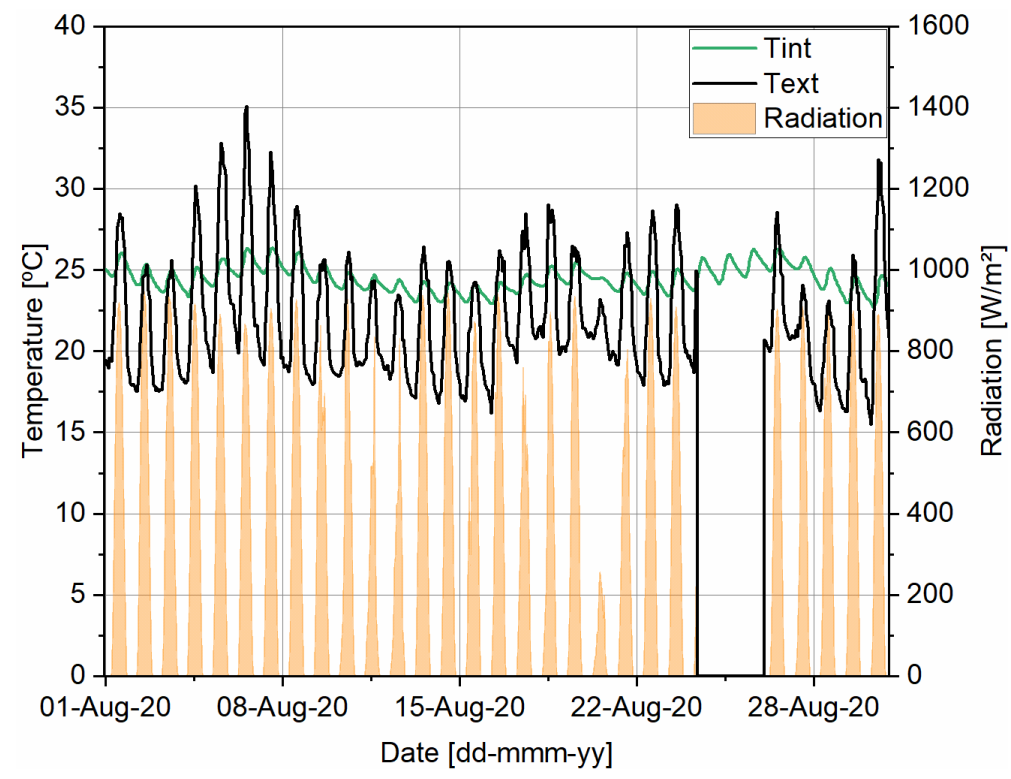

(b)

Figure 5. Environmental conditions during prototype testing: (a) February; (b) August.

Table 4. Monitored local environmental conditions in $2020\left[38.772^{\circ} \mathrm{N}, 9.178^{\circ} \mathrm{W}\right]$.

\begin{tabular}{ccc}
\hline Month & February & August \\
\hline & $0-24 \mathrm{~h}$ & \\
\hline $\mathrm{T}_{\text {ext,ave }}$ & 14.0 & 22.0 \\
$\mathrm{~T}_{\text {ext.min }}$ & 7.0 & 15.2 \\
$\mathrm{~T}_{\text {ext,max }}$ & 25.4 & 36.0 \\
\hline & $9-20 \mathrm{~h}$ & \\
\hline $\mathrm{T}_{\text {ext,ave }}$ & 16.7 & 25.0 \\
$\mathrm{~T}_{\text {ext.min }}$ & 10.5 & 18.2 \\
$\mathrm{~T}_{\text {ext.max }}$ & 25.7 & 36.0 \\
Radiation & 277 & 572 \\
Radiation $_{\text {max }}$ & 847 & 1166 \\
\hline
\end{tabular}

In order to present a detailed analysis of the thermal behavior of the BIPV-WS system, reference days for heating and cooling period were selected, characterized by high incident irradiance levels, and typical environment temperature, that best demonstrated the performance of the BIPV-WS prototype. The prototype was also tested according to two different operation modes, corresponding to the ventilated air cavity and the non-ventilated air cavity.

As such, from the collected weather data, February 21st, for the ventilated air cavity, and February 24th, for the non-ventilated cavity, were selected for the heating period (Figure 6a,b). For the cooling period, August 22nd, for the non-ventilated cavity, and August 30th, for the ventilated air cavity, were selected (Figure $6 c, d$ ).

As previously mentioned, these systems should be designed to operate differently in the heating season (ventilated through interior vents for heat recovery from the ventilated air cavity or non-ventilated air cavity, conserve the heat inside the air cavity, and diminish the heat losses) compared with the cooling period, where the ventilation was provided through external ventilation vents. The results are presented in the following section according to the season and respective operation scenario. 


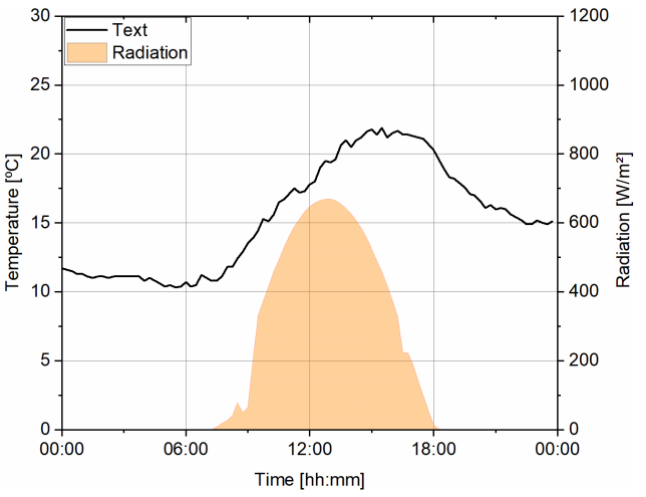

(a)

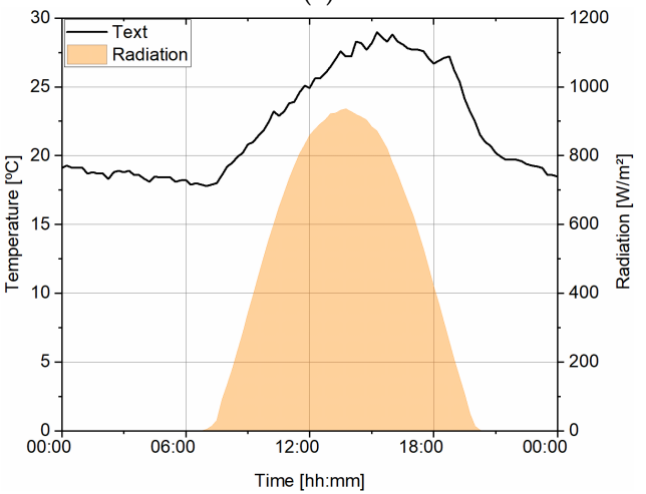

(c)

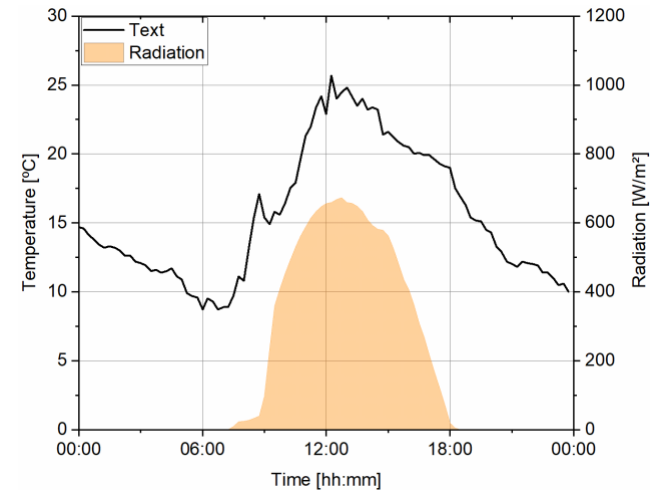

(b)

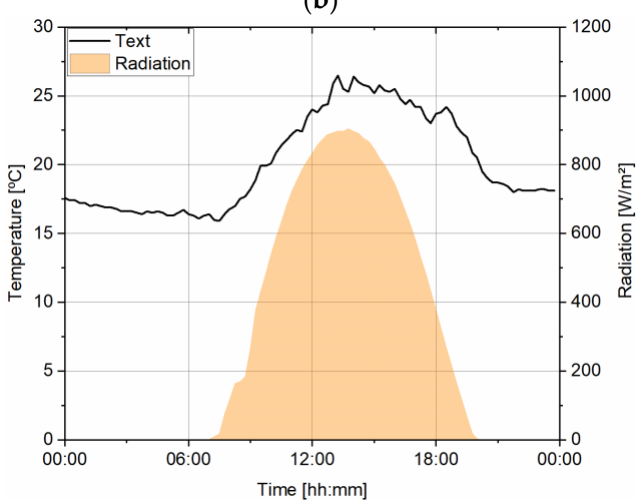

(d)

Figure 6. Environmental conditions during prototype testing: (a) February 21st, ventilated air cavity; (b) February 24th, non-ventilated air cavity; (c) August 22nd, non-ventilated air cavity; (d) August 30th, ventilated air cavity.

\subsection{BIPV-WS Winter Thermal Behaviour Results}

In the first analysis, the temperature profiles of each integrating layer of the BIPVWS system are presented for both scenarios related with the ventilated air cavity and non-ventilated air cavity (Figure 7). Figure 7 illustrates the cross-section of the BIPV-WS prototype, and the temperature profiles across the prototype at different hours of the day. The component with the highest temperature differential throughout the day was the $\mathrm{PV}$, which presented a difference between the maximum and minimum temperature of $39.7^{\circ} \mathrm{C}$ in the ventilated scenario and $45.6^{\circ} \mathrm{C}$ for the non-ventilated scenario. It is worth mentioning that the natural ventilation of the air cavity dropped the peak PV temperature by about $6^{\circ} \mathrm{C}$ in the peak radiation hour.

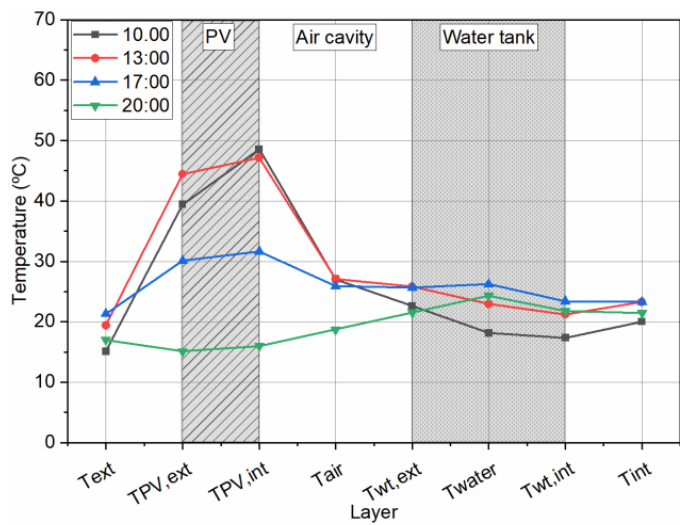

(a)

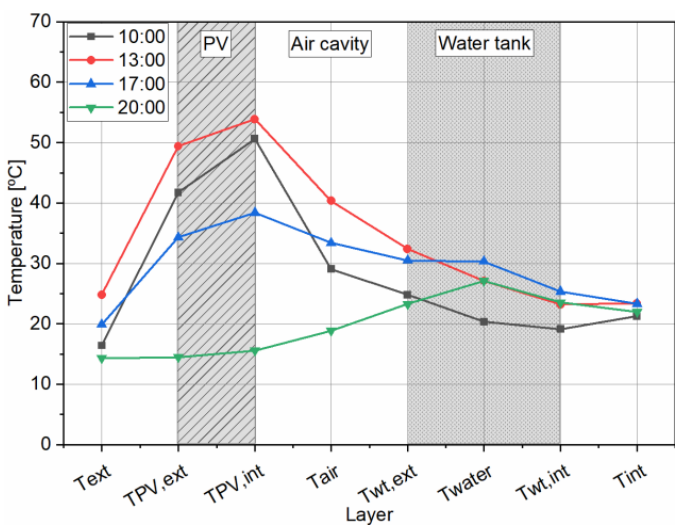

(b)

Figure 7. BIPV-WS thermal behavior: (a) February 21st, ventilated air cavity; (b) February 24th, non-ventilated air cavity. 
By comparing Figure $7 \mathrm{a}, \mathrm{b}$, the air cavity temperature reflects the influence of ventilation. Although at the beginning and the end of the day the temperature of the air cavity presented similar values in both evaluated scenarios, in the peak radiation hour, the temperature difference was up to $13^{\circ} \mathrm{C}$.

During the day, the water tank temperature presented temperatures between $16.8^{\circ} \mathrm{C}$ and $26.3^{\circ} \mathrm{C}$ for the ventilated air cavity, and $18.9^{\circ} \mathrm{C}$ and $30.5^{\circ} \mathrm{C}$ for the non-ventilated air cavity. On the other hand, it can be observed that the maximum temperature difference between the external and internal water tank surfaces was about $6.6^{\circ} \mathrm{C}$ for the ventilated scenario and $9.6^{\circ} \mathrm{C}$ for the non-ventilated scenario.

In the ventilated scenario, the air circulated between the indoor thermal zone and the BIPV-WS thermal zone through the opening of interior vents and free air circulation. In this scenario, the interior vents were opened at 10:42 $\mathrm{h}$ and closed at 18:00 $\mathrm{h}$.

The ventilation of the air cavity effects can be observed in the temperature profile of the air cavity and water temperature. In Figure 8, these temperatures are presented for both ventilated and non-ventilated air cavities.

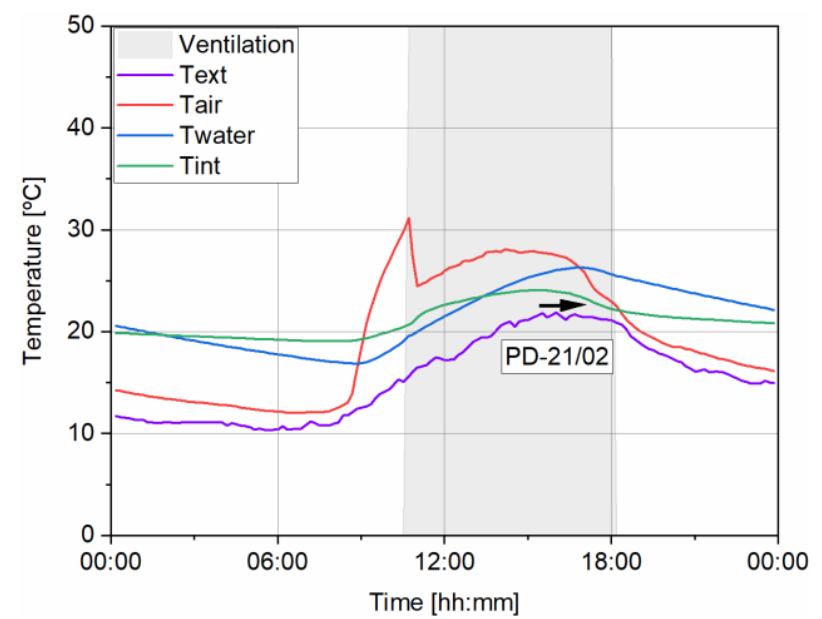

(a)

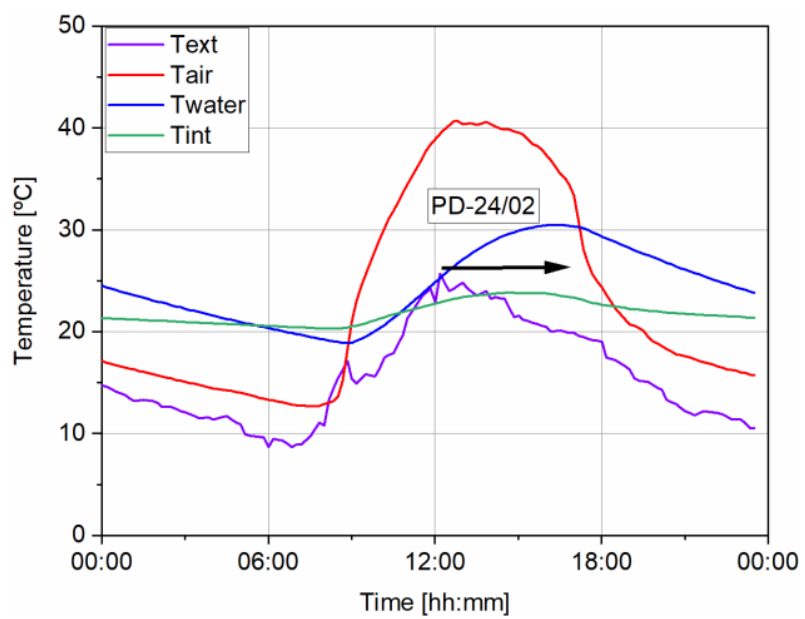

(b)

Figure 8. BIPV-WS layer temperature evolution: (a) February 21st, ventilated air cavity; (b) February 24th, non-ventilated air cavity.

Regarding the behavior of an air cavity, it can easily be observed that the temperature dropped down after opening the interior vents and ventilation was started, compared with the non-ventilated scenario, where the temperature inside the closed cavity continuously rose. The difference of maximum values of the temperature inside the air cavity was about $14{ }^{\circ} \mathrm{C}$ at the peak radiation hour between the ventilated and non-ventilated scenarios, demonstrating the ventilation effect in the air cavity temperature. Moreover, observing the water temperature profile, it can also be observed that the difference between the maximum values in the ventilated and non-ventilated air cavities was about $5{ }^{\circ} \mathrm{C}$.

The third aspect to be analyzed is the effect of the water heat storage capacity on the thermal behavior of the BIPV-WS in both the ventilated and non-ventilated scenarios. In the ventilated air cavity scenario, the water tank reached a peak temperature of $26.3^{\circ} \mathrm{C}$, at 16:50 $\mathrm{h}$, and maintained the temperature above $20^{\circ} \mathrm{C}$ for the remainder of the day. A delay of about $2 \mathrm{~h}$ between the maximum exterior temperature and water temperature (peak delay PD-21/02) can be observed in Figure 8. In the non-ventilated cavity scenario, the effect of water inertia can also be verified, with a delay of about $4 \mathrm{~h}$ between the peak temperature of the water and the outside temperature (PD-24/02).

The thermal behavior of the water tank temperature was highly influenced by the PV temperature, as expected. In the following, the analysis of the water temperature function of PV temperature is presented for both ventilated and non-ventilated air cavities. 
In Figure 9, it can be observed that the PV temperature started rising from sunrise (SR) at 7:20 $\mathrm{h}$, reaching above $40{ }^{\circ} \mathrm{C}$ around 10:00 $\mathrm{h}$ in both scenarios. When the ventilation vents were opened (OV), around 10:40 h, the PV temperature showed a drop in the ventilation scenario, while in the non-ventilated scenario (ventilation vents remain closed), the PV temperature continuously rose, reaching a maximum temperature of $51.8^{\circ} \mathrm{C}$, with a peak radiation $(\mathrm{PR})$ at $13: 30 \mathrm{~h}, 6^{\circ} \mathrm{C}$ higher than the maximum $\mathrm{PV}$ temperature in the ventilated scenario.

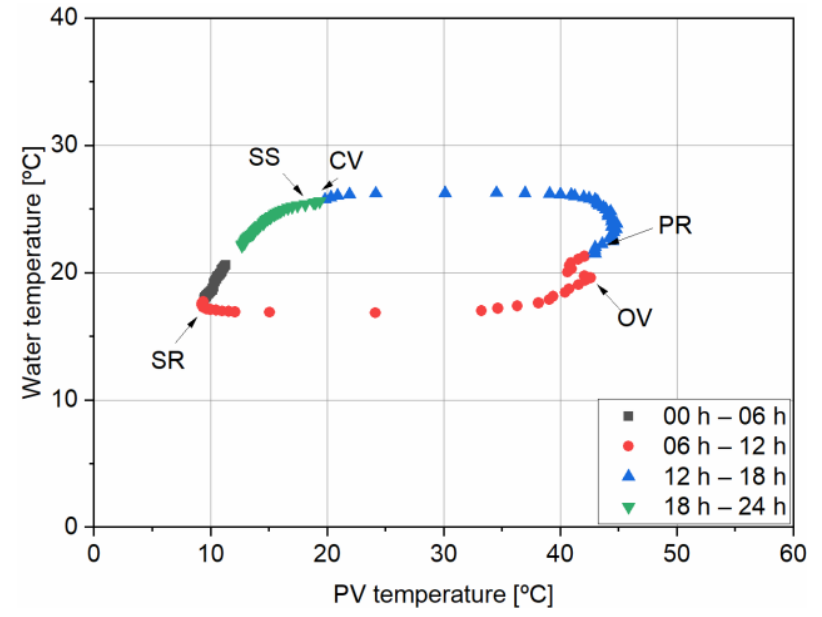

(a)

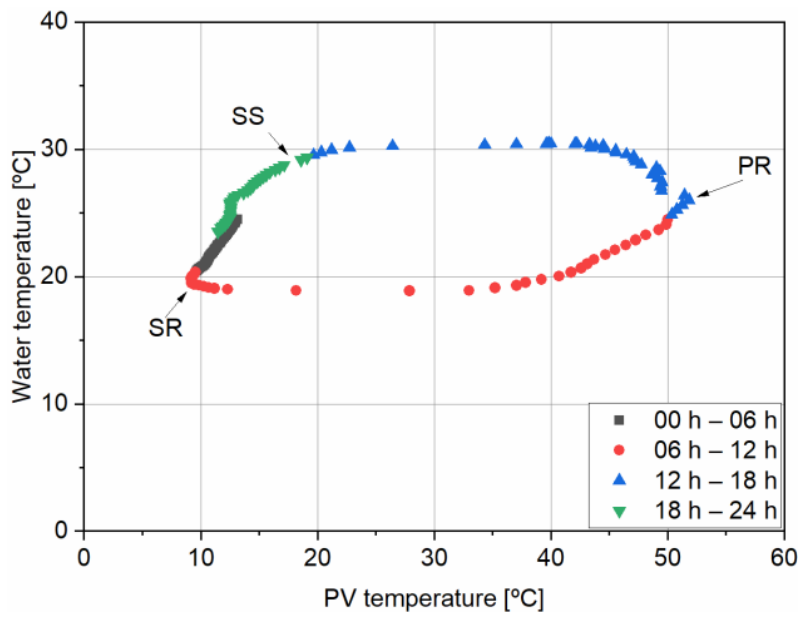

(b)

Figure 9. BIPV-WS water thermal behavior: (a) February 21st, ventilated air cavity; (b) February 24th, non-ventilated air cavity.

On the other hand, it can be observed that the water temperature followed the PV temperature trend, although with a significantly low variation during the day, due to its high thermal inertia. In this charging phase, the water temperature slowly increased from $8: 40 \mathrm{~h}\left(16.9^{\circ} \mathrm{C}\right)$ to a peak temperature of $30.5^{\circ} \mathrm{C}$ in the non-ventilated scenario, $4{ }^{\circ} \mathrm{C}$ higher than in the ventilated scenario. Moreover, it is worth mentioning that the water temperature remained above $20{ }^{\circ} \mathrm{C}$ even after sunset (SS), when the discharging phase started, for about $11 \mathrm{~h}$ in the ventilated scenario and $12 \mathrm{~h}$ in the non-ventilated scenario, evidencing the thermal storage potential and solution for limiting heat losses.

\subsection{BIPV-WS Summer Thermal Behaviour Results}

Although the non-ventilated scenario is usually not considered as a solution for the summer period with the presented climate conditions, due to possibilities of overheating, an analysis was performed for a comparison with the ventilated scenario.

Similarly, for the winter season, an analysis of the temperature profiles of each integrating layer of the BIPV-WS system was performed for both ventilation scenarios. During the cooling season, air circulates during the whole day between the BIPV-WS air cavity and the outside, through the opening of the exterior vents. The graphical representation of these temperatures at different time steps on these sunny days allows drawing several conclusions. The temperature profiles through the system cross section for both summer days, representing non-ventilated and ventilated scenarios, respectively, are presented in Figure 10 for different periods of the day.

The exterior temperature on the two summer days chosen for testing for ventilated and non-ventilated scenarios were slighting different, about $2{ }^{\circ} \mathrm{C}$ at different hours along the day. However, it can be observed that the surface temperatures generally maintained the same difference between both scenarios. The indoor temperature also did not verify differences between both scenarios. 


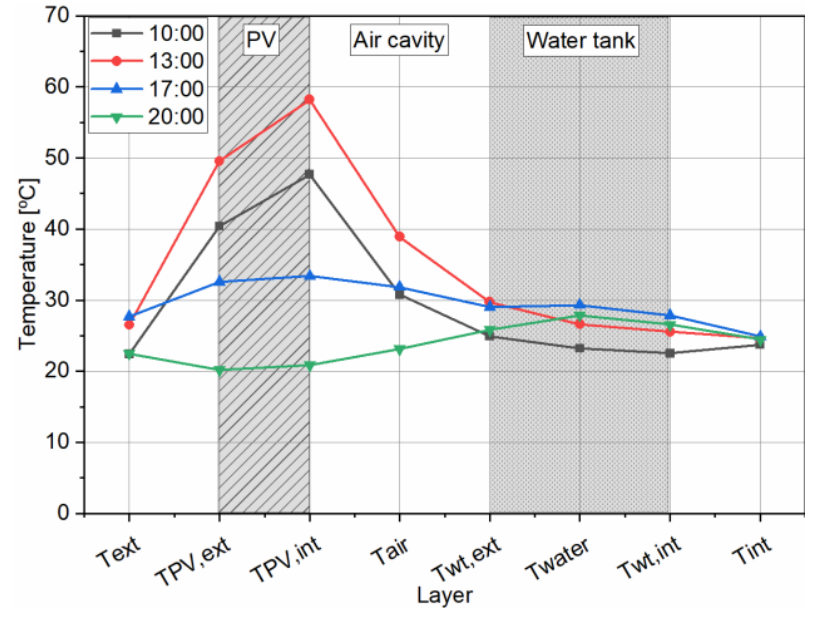

(a)

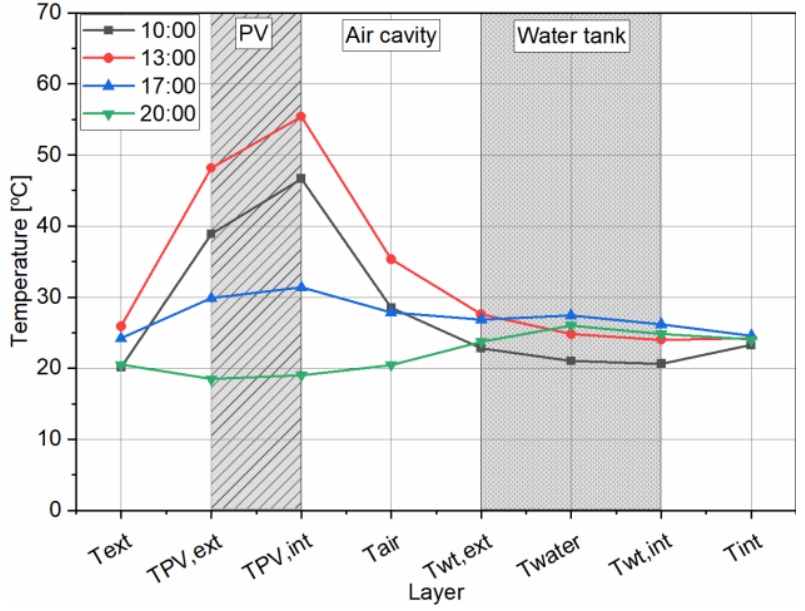

(b)

Figure 10. BIPV-WS thermal behavior: (a) August 22nd, non-ventilated air cavity; (b) August 30th, ventilated air cavity.

The ventilation of the air cavity effects can also be observed in the summer conditions, in the temperature profile of the air cavity. In Figure 11, these temperatures are presented for both scenarios.

It can be observed that the difference between the maximum air cavity temperature in both scenarios was about $4{ }^{\circ} \mathrm{C}$, during the peak radiation hour; thus, the air ventilation successfully released the produced heat to the exterior.

A delay of about $4 \mathrm{~h}$ between the maximum exterior temperature and water temperature in both scenarios (PD-22/08 and PD-30/08) can be observed in Figure 11.

During the day, the water tank temperature presented temperatures between $22.4{ }^{\circ} \mathrm{C}$ and $29.4{ }^{\circ} \mathrm{C}$ in the non-ventilated scenario and between $20{ }^{\circ} \mathrm{C}$ and $27.5{ }^{\circ} \mathrm{C}$ in the ventilated scenario. In both scenarios, the peak water temperature was reached around the same time period (17:00 h).

Between 00:00 $\mathrm{h}$ and 08:30 $\mathrm{h}$, in the non-ventilated scenario, the cavity air temperature remained between $19{ }^{\circ} \mathrm{C}$ and $20^{\circ} \mathrm{C}$, which caused the temperature of the water to decrease from $25.5^{\circ} \mathrm{C}$ to $23.5^{\circ} \mathrm{C}$. In the ventilated scenario, the cavity air temperature was lower, enabling the temperature of the water tank to decrease further.

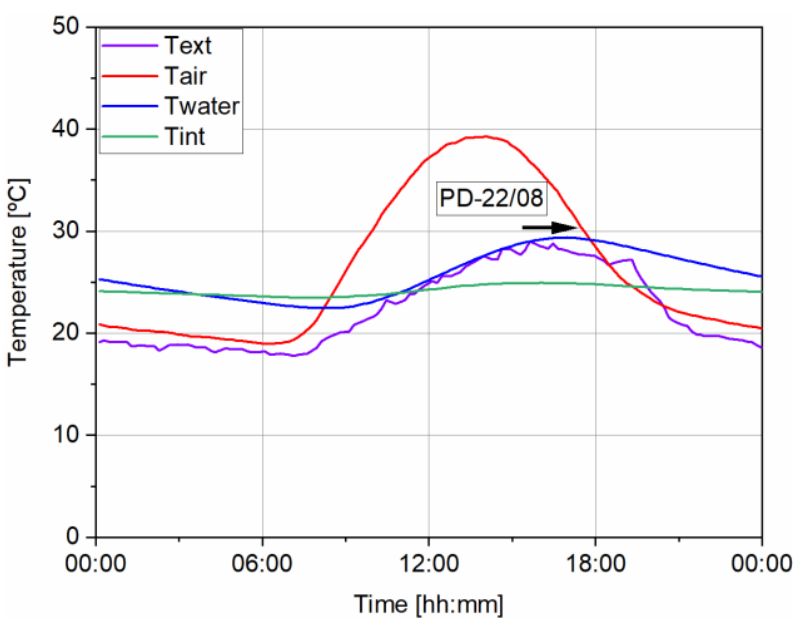

(a)

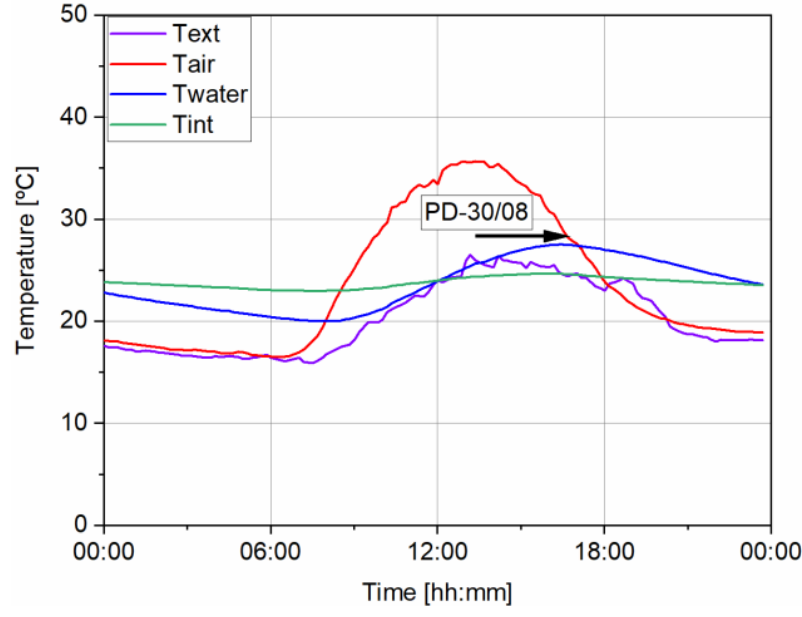

(b)

Figure 11. BIPV-WS layer temperature evolution: (a) August 22nd, non-ventilated air cavity; (b) August 30th, ventilated air cavity. 
By comparing the water temperature with the indoor space temperature, in the ventilated scenario, the results show that the water temperature remained below the office air temperature until 12:30 h. In the non-ventilated scenario, the water temperature remained below the office air temperature between 03:30 $\mathrm{h}$ and 11:00 $\mathrm{h}$, indicating less beneficial office nocturnal heat loss in the non-ventilated scenario.

In the cooling season, the thermal behavior of the water temperature was quite similar to its behavior during the heating period.

In Figure 12, the analysis of the water temperature function of the PV temperature is presented for the non-ventilated air cavity scenario (a) and the ventilated air cavity scenario (b).

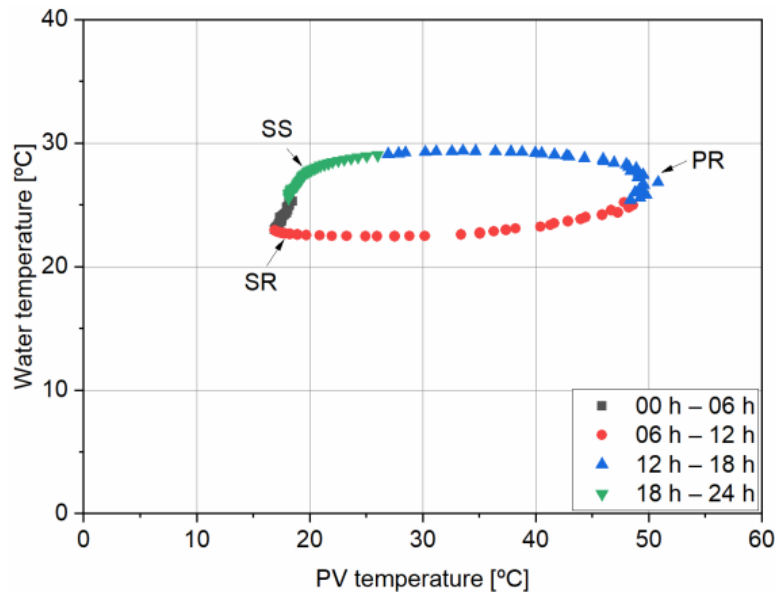

(a)

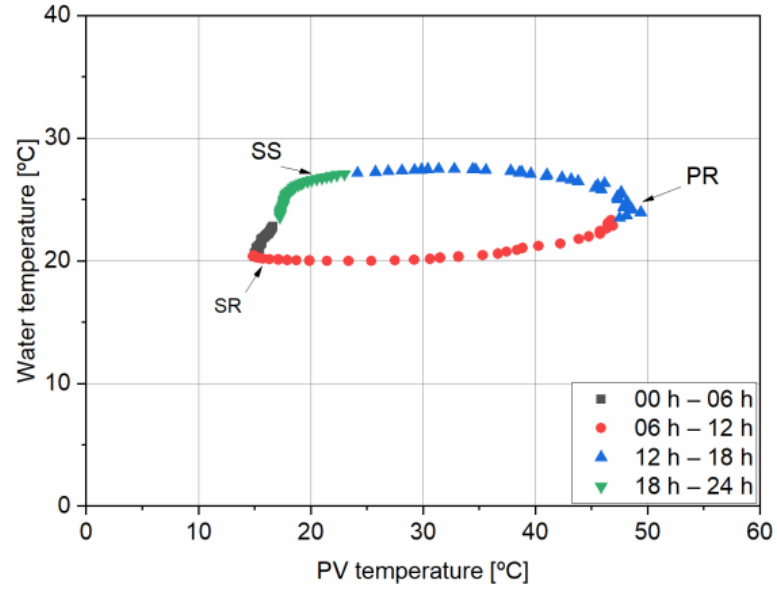

(b)

Figure 12. BIPV-WS water thermal behavior: (a) August 22nd, non-ventilated air cavity; (b) August 30th, ventilated air cavity.

The PV temperature started rising from sunrise (SR) up to $50{ }^{\circ} \mathrm{C}$ at $13: 00 \mathrm{~h}$ in both scenarios. Compared with the same periods in February, an increase of PV and water temperature was verified, although this increase was slower as a consequence of a different sun position in the cooling and heating seasons. The PV temperature started to decrease at 15:00 $\mathrm{h}$, registering about $20^{\circ} \mathrm{C}$ around sunset (SS) for both scenarios.

Regarding the water temperature, it can be observed that the increasing temperature related with the charging phase was lower than in the heating period for both the ventilated and non-ventilated scenarios, equivalent to a $2{ }^{\circ} \mathrm{C}$ difference between SR and PR.

The water temperature reached the maximum value at 17:00 $\mathrm{h}$ with temperatures of $30{ }^{\circ} \mathrm{C}$ and $27.5^{\circ} \mathrm{C}$ for the non-ventilated and ventilated scenarios, respectively, remaining around this temperature for the rest of the day, cooling down only after the sun had completely set.

Although the water temperature showed high values during the day time, it can be observed that in the discharging phase starting at SS, the water temperature dropped down from $25.3^{\circ} \mathrm{C}$ to $22.4{ }^{\circ} \mathrm{C}$ between 00:00 $\mathrm{h}$ and $06: 00 \mathrm{~h}$ in the non-ventilated scenario and from $22.7^{\circ} \mathrm{C}$ to $20^{\circ} \mathrm{C}$ in the ventilated scenario.

\subsection{BIPV-WS Performance Results}

As mentioned, these systems were designed to make use of thermal and electrical energy, increasing the amount of total useful energy produced by the PV panels. For the evaluation of the energy and thermal performance of the BIPV-WS system, the electrical and thermal efficiency was calculate using the following expressions used in [19]:

$$
\eta_{e}=\frac{P}{G \times A},
$$




$$
\eta_{t}=\frac{q_{\text {int }}+q_{v}}{G \times A}
$$

In Equation (2), the electrical efficiency is defined as the quotient between the power produced $(P)$ and the incident solar radiation rate $(G)$ multiplied by the superficial area $(A)$. In Equation (3), the thermal efficiency is the quotient between the thermal gains into the acclimatized space through the wall $\left(q_{\text {int }}\right)$ by conduction and through ventilation $\left(q_{v}\right)$. As such, to distinguish the thermal efficiencies for the cooling and heating periods, Equations (4) and (5) were used, taking into account a global analysis of the system during insolation:

$$
\begin{aligned}
\eta_{t . w i n t e r} & =\frac{\sum\left(q_{\text {int }}+q_{v}\right)}{\sum(G \times A)}, \\
\eta_{t, \text { summer }} & =\frac{\sum\left(q_{v}-q_{\text {int }}\right)}{\sum(G \times A)},
\end{aligned}
$$

The thermal gains through the water tank were determined through the contributions of the convective and radiative heat transfer of the water tank interior surface, presented in Equations (6)-(10) [28]:

$$
\begin{gathered}
q_{i n t, c o n v}=A h_{w t, i n t}\left(T_{w t, i n t}-T_{i n t}\right), \\
q_{i n t, r a d}=A \varepsilon \sigma\left(T_{w t, i n t}{ }^{4}-T_{i n t}{ }^{4}\right), \\
h_{w t, i n t}=\frac{\overline{N u_{L}} k}{L}, \\
\overline{N u_{L}}=0.68+\frac{0.67 R a_{L}{ }^{1 / 4}}{\left[1+\left(\frac{0.492}{P r}\right)^{9 / 16}\right]^{4 / 9},} \\
R a_{L}=\frac{g \beta\left(T_{w t, i n t}-T_{i n t}\right) L^{3}}{v \alpha},
\end{gathered}
$$

where $q_{\text {int,conv }}$ and $q_{\text {int,rad }}$ represent the heat transfer into the test room by the interior water tank wall by convection and radiation, respectively. $T_{w t, i n t}$ is the water tank interior surface temperature and $T_{i n t}$ the temperature of the indoor space. $h_{w t, \text { int }}$ represents the convection coefficient, $\varepsilon$ the emissivity of the interior surface, and $\sigma$ the Stefan-Boltzmann constant. To determine the convection coefficient, the Nusselt number, $\overline{N u_{L}}$, is multiplied by the film air thermal conductivity and divided by the vertical plate's length. As the flow is laminar, the Nusselt number is determined using Equation (9), a function of the Rayleigh number, $R a_{L}$, and the Prandtl number, Pr. In Equation (10), the Rayleigh number is a function of, aside from the mentioned variables, the gravity acceleration $g$ and the film air thermal properties, such as the thermal expansion coefficient $\beta$, the kinematic viscosity $v$, and the thermal diffusivity $\alpha$. The thermal gains through ventilation were calculated by Equation (11) [29], consisting of the balance of enthalpy gain and loss:

$$
q_{v}=\dot{v} \rho C_{p}\left(T_{\text {air }}-T_{\text {int }}\right),
$$

where the airflow rate $(\dot{v})$ is multiplied by the air specific heat $\left(C_{p}\right)$ and air density $(\rho)$ and the difference between the air entering and leaving the acclimatized space. To determine the airflow rate, Equation (12) [30] was used:

$$
\dot{v}=C_{D} A \sqrt{\frac{2 g h\left(T_{a i r}-T_{\text {int }}\right)}{T_{\text {air }}}},
$$

where $C_{D}$ is the discharge coefficient, $A$ the airflow area, $g$ the standard gravity acceleration and $h$ the vertical distance between the inlet and outlet midpoints. This equation provides an approximate relation, as losses at the chamber entrance and exit, resulting from the curvature of the airflow path, are not accounted for. 
Furthermore, PV electrical efficiency increases as the module temperature decreases [17,31], shown in Equation (13), attaching an additional benefit to BIPV with airflow configurations:

$$
\eta_{e}=\eta_{R}\left(1-\beta\left(T_{P V}-T_{N O C T}\right)\right),
$$

where $\eta_{R}$ describes the $\mathrm{PV}$ reference efficiency, $\beta$ describes the temperature coefficient $\left(k^{-1}\right)$, $T_{P V}$ is the measured PV cell temperature $\left({ }^{\circ} \mathrm{C}\right)$, and $T_{N O C T}$ represents the cell Nominal Operating Cell Temperature $\left({ }^{\circ} \mathrm{C}\right)$.

\subsubsection{BIPV-WS Winter Performance}

During the winter, the thermal energy produced by the PV panels can be utilized to aid the indoor space heating, reducing the energy needs from active heating systems, while also lowering the PV cell temperature. Following Equation (13), and using data from [26] and the measured PV cell temperature, the BIPV-WS electrical efficiency was calculated for both ventilated and non-ventilated air cavity scenarios, during the period of the ventilation and irradiation. The results are presented in Figure 13.

In Figure 13, it can be observed that the ventilated cavity scenario had a higher $\eta_{e} / \eta_{R}$ ratio than the non-ventilated cavity scenario, ensuring increased PV power production. Moreover, data for the ventilated cavity scenario indicated an electrical efficiency higher than the reference efficiency. This is because, through natural ventilation due to the opening of the vents (OV), the PV cell temperature was maintained below the indicated NOCT of $47^{\circ} \mathrm{C}$.

As mentioned, one of the objectives is to use the heat recovered in the conversion process for interior space heating through ventilation. For the evaluation of the thermal capabilities of the BIPV-WS, the thermal efficiency of the system using Equation (4) was calculated for both scenarios and during the ventilation and insolation time. The results are presented in Figure 14.

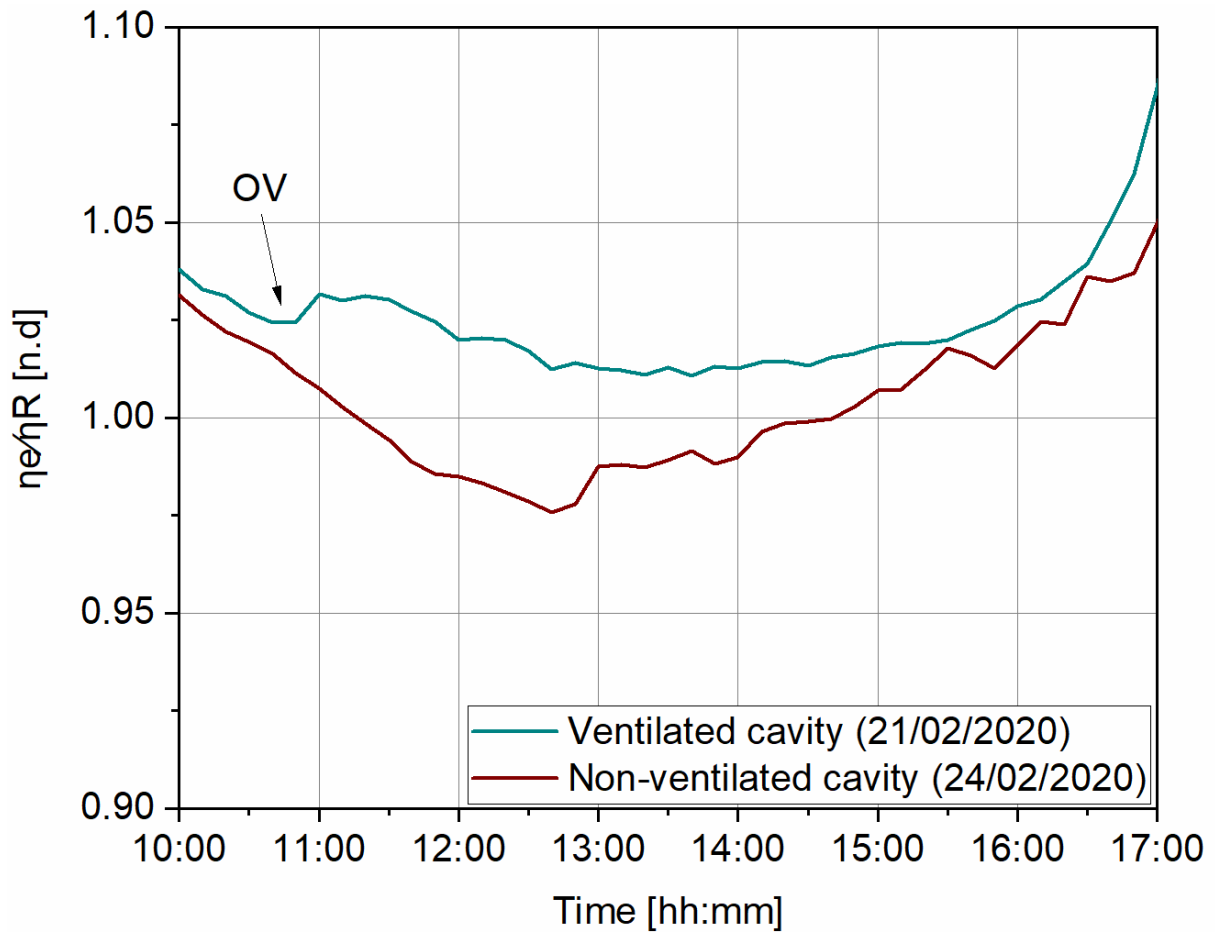

Figure 13. BIPV-WS electrical efficiency behavior for winter conditions. 


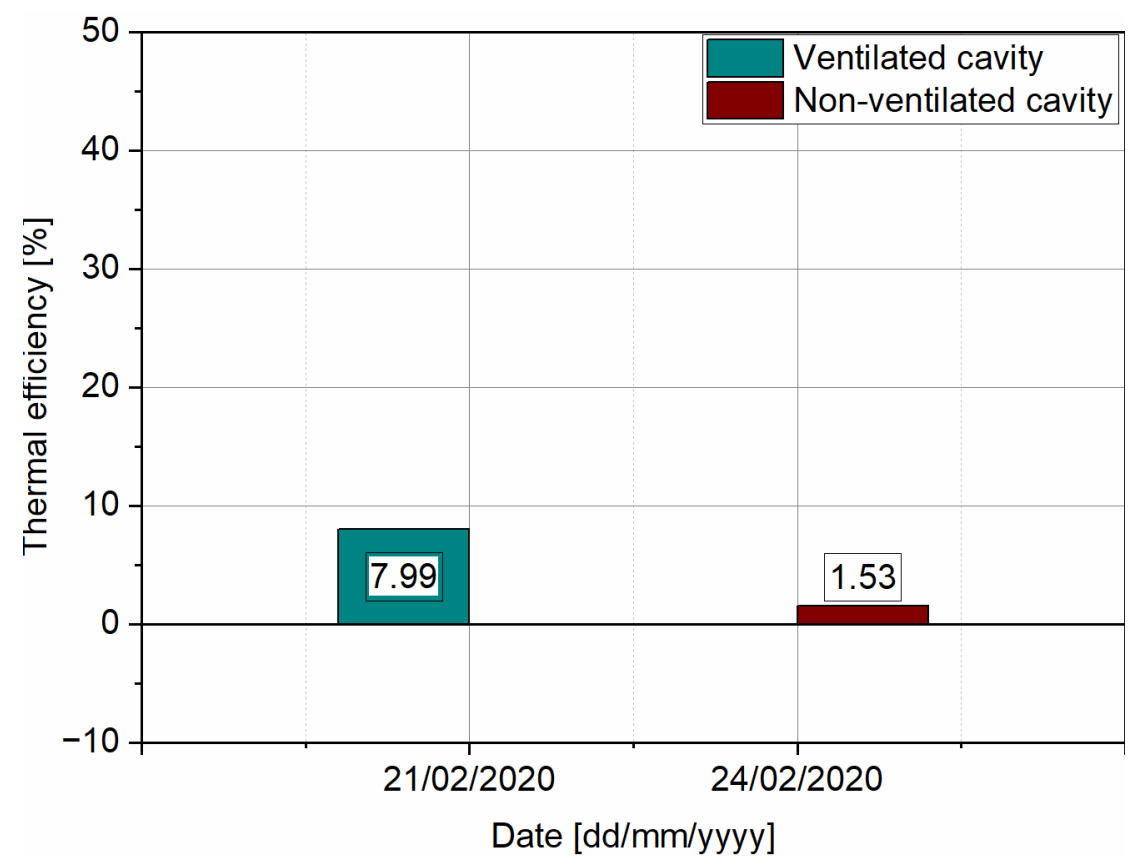

Figure 14. BIPV-WS thermal efficiency behavior for winter conditions.

Taking into account the thermal gains and the solar radiation throughout insolation, for the ventilated scenario, the BIPV-WS registered a thermal efficiency of $7.99 \%$, while for the non-ventilated scenario, the thermal efficiency reached $1.53 \%$, demonstrating that the ventilation mode provided more heating into the adjacent space.

\subsubsection{BIPV-WS Summer Performance}

In Figure 15, an analysis of the BIPV-WS electric efficiency is presented for the ventilated air cavity and the non-ventilated air cavity modes, during insolation. Similar to the winter scenario, it can be observed that the ventilated air cavity scenario had a higher $\eta_{e} / \eta_{R}$ ratio than the non-ventilated air cavity scenario, due to the lower measured cell temperature. The ventilation effect was more notable during the afternoon, as the atmosphere air cooled down and ensured improved PV cell cooling, improving cell electrical efficiency and power production.

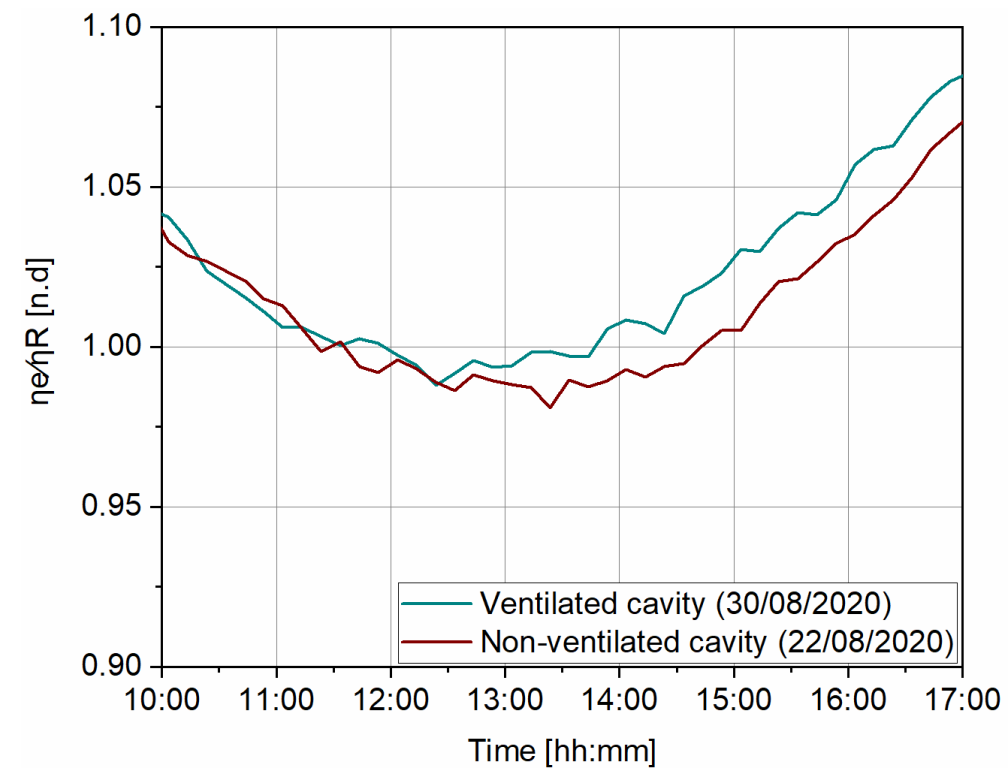

Figure 15. BIPV-WS electrical efficiency behavior for summer conditions. 
While heating is usually undesired during the cooling period, it is worth studying the BIPV-WS thermal performance for the summer through Equation (5). Figure 16 presents the thermal efficiency of BIPV-WS prototype during the analyzed summer days. Taking into account the thermal gains during insolation, the ventilated configuration presented a thermal efficiency of $40.03 \%$, while the non-ventilated configuration presented a thermal efficiency of $-3.84 \%$. The negative thermal efficiency presented in the non-ventilated air cavity scenario stemmed from the thermal energy being transferred into the adjacent space, which is undesired. Conversely, the thermal efficiency in the ventilated air cavity scenario resulted from the thermal energy being successfully discharged to the outdoors.

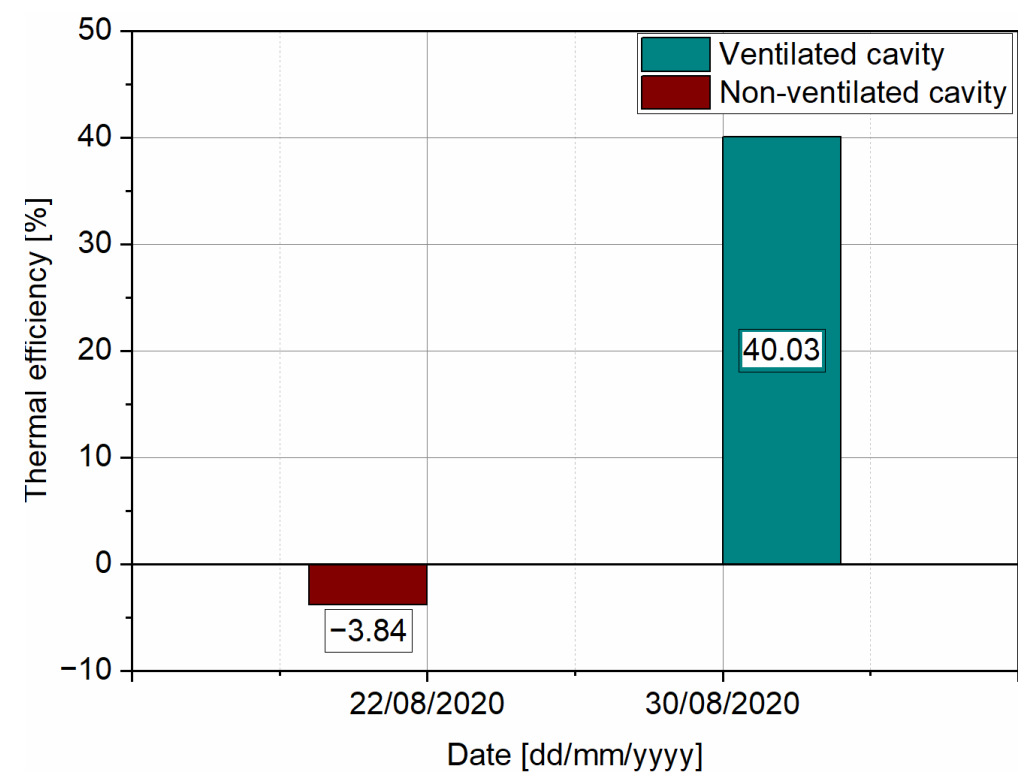

Figure 16. BIPV-WS thermal efficiency behavior for summer conditions.

\section{Conclusions}

In this research, an experimental investigation of a Building-Integrated Photovoltaic prototype combined with a water storage tank (BIPV-WS) as part of a façade of the building Solar XXI was performed. This investigation is part of the current research project NZEB_LAB, of which the aim is to promote testing and development of all applications of solar energy in buildings.

The thermal behavior of each layer of the prototype was analyzed for typical clear winter and summer days in Lisbon, Portugal, taking into account the temperatures of the PV module, the air cavity, and the water tank. The behavior of the water tank as a storage element was also analyzed through a temperature analysis.

For winter conditions, it was observed that not only the prototype would supply the office space with heated air, but also the water storage proved to be an effective thermal storage component, keeping a temperature above $20{ }^{\circ} \mathrm{C}$ for about $11 \mathrm{~h}$ after its peak temperature, reducing heat losses to the exterior after sunset.

For summer conditions, the water tank proved to successfully prevent indoor space heating during the morning and aid in delaying the space heating through thermal storage, reducing the potential cooling needs during occupation and increasing occupant thermal comfort.

In both scenarios, the PV panel temperature reduction was observed in the ventilated configuration, due to airflow and natural convection, increasing the PV module's electrical efficiency, while also reducing the risk of overheating when compared with non-ventilation configuration. In both scenarios, the thermal efficiency presents superior values in the ventilated configuration (almost $8 \%$ in the heating period and about $40 \%$ in the cooling period) compared with the non-ventilated configuration $(1.5 \%$ in the heating period and $3.8 \%$ in the cooling period). 
This work provides an additional assessment of BIPV-WS as a solution to reducing heat losses and heating needs in the winter, and also as a thermal damper during the summer, delaying heating during occupation and reducing acclimatization needs.

Being an experimental study with a monitoring campaign conducted over a relatively short period of time during winter and summer in order to assure the same environmental conditions for both ventilated and non-ventilated operation modes, the wider applicability of the specific findings from this study should be questioned. Future research will need to address the yearly operation and performance.

Author Contributions: Conceptualization, L.A., J.F., and H.G.; methodology, L.A. and M.S.; validation, M.S.; formal analysis, J.M.L., M.S., and L.A.; investigation, L.A.; resources, J.F. and H.G.; data curation, J.M.L. and M.S.; writing_-original draft preparation, M.S.; writing—review and editing, J.M.L., M.S., and L.A.; supervision, L.A. and J.F.; project administration, L.A., J.F., and H.G.; funding acquisition, J.F. and H.G. All authors have read and agreed to the published version of the manuscript.

Funding: This research was funded by SUDOKET-Mapping, consolidation and dissemination of the Key Enabling Technologies (KETs) for the construction sector in the SUDOE space. The construction of the prototypes was funded by FCT/MEC (PIDDAC) and the European FEDER from the Regional Operation Program of Lisbon, Ref. LISBOA-01-0145-FEDER-022075.

Institutional Review Board Statement: Not applicable.

Informed Consent Statement: Not applicable.

Data Availability Statement: The data presented in this study are available on request from the corresponding author.

Acknowledgments: SUDOKET-Mapping, consolidation and dissemination of the Key Enabling Technologies (KETs) for the construction sector in the SUDOE space is financed through funds from the Interreg Sudoe Program, co-financed by the European Regional Development Fund (ERDF). NZEB_LAB - Research Infrastructure on Integration of Solar Energy Systems in Buildings (REF. LISBOA-01-0145-FEDER-02275) is financed by national funds FCT/MEC (PIDDAC) and the European FEDER from the Regional Operation Program of Lisbon.

Conflicts of Interest: The authors declare no conflict of interest.

\section{Appendix A}

Table A1. Monitored local environmental conditions in $2020\left[38.772{ }^{\circ} \mathrm{N}, 9.178^{\circ} \mathrm{W}\right]$.

\begin{tabular}{ccccccccccccc}
\hline Month & $\mathbf{1}$ & $\mathbf{2}$ & $\mathbf{3}$ & $\mathbf{4}$ & $\mathbf{5}$ & $\mathbf{6}$ & $\mathbf{7}$ & $\mathbf{8}$ & $\mathbf{9}$ & $\mathbf{1 0}$ & $\mathbf{1 1}$ & $\mathbf{1 2}$ \\
\hline & \multicolumn{10}{c}{$0-24 \mathrm{~h}$} \\
\hline $\mathrm{T}_{\text {ext,ave }}$ & 11.6 & 14.0 & 14.1 & 15.0 & 18.7 & 19.8 & 24.4 & 22.0 & 22.4 & 17.2 & 15.1 & 12.1 \\
$\mathrm{~T}_{\text {ext,min }}$ & 2.7 & 7.0 & 6.0 & 5.2 & 11.1 & 12.1 & 15.2 & 15.2 & 14.4 & 9.1 & 7.8 & 0.7 \\
$\mathrm{~T}_{\text {ext,max }}$ & 20.1 & 25.4 & 27.7 & 25.1 & 35.6 & 33.8 & 41.5 & 36.0 & 37.2 & 29.0 & 25.1 & 21.0 \\
\hline & \multicolumn{10}{c}{} & \multicolumn{10}{c}{$9-20 \mathrm{~h}$} \\
\hline $\mathrm{T}_{\text {ext,ave }}$ & 13.3 & 16.7 & 16.6 & 17.5 & 21.8 & 22.7 & 28.7 & 25.0 & 25.8 & 19.8 & 17.0 & 13.7 \\
$\mathrm{~T}_{\text {ext,min }}$ & 3.8 & 10.5 & 7.0 & 8.9 & 12.5 & 13.9 & 18.0 & 18.2 & 16.3 & 12.4 & 8.9 & 5.2 \\
$\mathrm{~T}_{\text {ext,max }}$ & 20.1 & 25.7 & 27.7 & 25.1 & 35.6 & 33.8 & 41.5 & 36.0 & 37.2 & 29.0 & 25.1 & 21.0 \\
Radiation $_{\text {ave }}$ & 184 & 277 & 391 & 394 & 543 & 627 & 668 & 572 & 456 & 320 & 187 & 167 \\
Radiation $_{\max }$ & 744 & 847 & 1170 & 1275 & 1244 & 1414 & 1024 & 1166 & 1065 & 986 & 728 & 723 \\
\hline
\end{tabular}

\section{References}

1. European Parlament. Directive 2010/31/EU of the European Parliament and of the Council of 19 May 2010 on the Energy Performance of buildIngs. 2010. Available online: https: / eur-lex.europa.eu/eli/dir/2010/31/oj (accessed on 26 February 2021).

2. European Commission. Commission Recommendation (EU) 2016/1318. 2016. Available online: https:/ / eur-lex.europa.eu/legalcontent/EN/TXT/?uri=CELEX\%3A32016H1318 (accessed on 26 February 2021). 
3. Athienitis, A.; Zhang, J.; Feldman, D. A study of double facades with phase-change storage and photovoltaics. In Proceedings of the 1st International Conference on Passive and Low Energy Cooling for the Built Environment, Santorini, Greece, 19-21 May 2005.

4. Aelenei, L.; Frattari, A.; Riscala, L.; Altan, H.; Hashemi, A.; Aoul, K.A.T.; Noguchi, M. Zero Energy Homes. In ZEMCH: Toward the Delivery of Zero Energy Mass Custom Homes; Springer: Berlin/Heidelberg, Germany, 2016; pp. 275-309.

5. Garde, F.; Ayoub, J.; Aelenei, L.; Aelenei, D.; Scognamiglio, A. Solution Sets for Net Zero Energy Buildings: Feedback from 30 Buildings Worldwide; John Wiley \& Sons: Hoboken, NJ, USA, 2017; ISBN 343360469X.

6. Bouzoukas, A. New approaches for Cooling Photovoltaic/Thermal (PV/T) Systems. Ph.D. Thesis, University of Nottingham, Nottingham, UK, 2008.

7. Agrawal, B.; Tiwari, G.N. Optimizing the energy and exergy of building integrated photovoltaic thermal (BIPVT) systems under cold climatic conditions. Appl. Energy 2010, 87, 417-426. [CrossRef]

8. Lloret, A.; Andreu, J.; Merten, J. The Mataro Library: A 53kWp grid connected building with integrated PV-thermal multifunctional modules. In Proceedings of the 13th European PV Solar Energy Conference, Nice, France, 23-27 October 1995; pp. 490-493.

9. Chen, Y.; Athienitis, A.K.; Galal, K.E.; Poissant, Y. Design and simulation for a solar house with building integrated photovoltaicthermal system and thermal storage. In Proceedings of the ISES Solar World Congress, Beijing, China, 18-21 September 2007; Springer: Heidelberg, Germany, 2007; Volume 1, p. 327. [CrossRef]

10. Liao, L.; Athienitis, A.K.; Candanedo, L.; Park, K.W.; Poissant, Y.; Collins, M. Numerical and experimental study of heat transfer in a BIPV-thermal system. J. Sol. Energy Eng. 2007, 129, 423-430. [CrossRef]

11. Bot, K.; Aelenei, L.; Gomes, M.D.G.; Santos Silva, C. Performance assessment of a building integrated photovoltaic thermal system in mediterranean climate-A numerical simulation approach. Energies 2020, 13, 2887. [CrossRef]

12. Lourenço, J.M.; Aelenei, L.; Facão, J.; Aelenei, D.; Pina, J.M. Aplicação das tecnologias facilitadoras essenciais (TFE) na gestão, controlo e monitorização inteligente de edifícios. In CIES2020: As Energias Renováveis na Transição Energética: Livro de Comunicações do XVII Congresso Ibérico e XIII Congresso Ibero-Americano de Energia Solar; Gonçalves, H., Romero, M., Eds.; LNEG: Lisboa, Portugal, 2020; pp. 1069-1077. [CrossRef]

13. Aelenei, L.; Pereira, R.; Ferreira, A.; Gonçalves, H.; Joyce, A. Building integrated photovoltaic system with integral thermal storage: A case study. Energy Procedia 2014, 58, 172-178. [CrossRef]

14. Aelenei, D.; Lopes, R.A.; Aelenei, L.; Gonçalves, H. Investigating the potential for energy flexibility in an office building with a vertical BIPV and a PV roof system. Renew. Energy 2019, 137, 189-197. [CrossRef]

15. Sousa, M.A.C.; Aelenei, L.; Gonçalves, H. Comportamento térmico de um protótipo BIPV combinado com armazenamento de água: Análise experimental. In CIES2020: As Energias Renováveis na Transição Energética: Livro de Comunicações do XVII Congresso Ibérico e XIII Congresso Ibero-Americano de Energia Solar; Gonçalves, H., Romero, M., Eds.; LNEG: Lisboa, Portugal, 2020; pp. 1167-1174. [CrossRef]

16. Aelenei, L.; Pereira, R.; Gonçalves, H.; Athienitis, A. Thermal Performance of a Hybrid BIPV-PCM: Modeling, Design and Experimental Investigation. Energy Procedia 2014, 48, 474-483. [CrossRef]

17. Koyunbaba, B.K.; Yilmaz, Z.; Ulgen, K. An approach for energy modeling of a building integrated photovoltaic (BIPV) Trombe wall system. Energy Build. 2013, 67, 680-688. [CrossRef]

18. Charron, R.; Athienitis, A. Optimization of the performance of double-façades with integrated photovoltaic panels and motorized blinds. Solar Energy 2006, 80, 482-491. [CrossRef]

19. Pereira, R.; Aelenei, L. Optimization assessment of the energy performance of a BIPV/T-PCM system using Genetic Algorithms. Renew. Energy 2019, 137, 157-166. [CrossRef]

20. Wu, T.; Lei, C. A review of research and development on water wall for building applications. Energy Build. 2016, 112, 198-208. [CrossRef]

21. Aelenei, L.; Pereira, R.; Gonçalves, H. BIPV/T versus BIPV/T-PCM: A numerical investigation of advanced system integrated into Solar XXI building façade. In Proceedings of the 2nd International Conference on Sustainable Energy Storage Book of Proceedings, Dublin, Ireland, 19-21 June 2013.

22. Objectives-NZEB_LAB. Available online: https://nzeblab.lneg.pt/?page_id=71 (accessed on 27 February 2021).

23. Aelenei, L.; Gonçalves, H. From solar building design to net zero energy buildings: Performance insights of an office building. Energy Procedia 2014, 48, 1236-1243. [CrossRef]

24. Gonçalves, H.; Cabrito, P.; Diniz, I. Solar XXI: Em Direcção à Energia Zero: Towards Zero Energy; LNEG: Lisboa, Portugal, 2010; 61p, ISBN 978-989-675-007-7.

25. Gonçalves, H.; Aelenei, L.; Rodrigues, C. Solar XXI: A Portuguese office building towards net zero-energy building. REHVA Eur. HVAC J. 2012, 49, 34-40.

26. Datasheet_ESPMC150. Available online: https://www.atersa.es/Common/pdf/atersa/manuales-usuario/modulosfotovoltaicos/Datasheet_ESPMC150.pdf (accessed on 26 April 2021).

27. Policarbonato Compacto-VF1'_2016. Available online: https://www.dagol.com/wp-content/uploads/2016/10/folheto-policompacto.pdf (accessed on 11 April 2021).

28. Bergman, T.-L.; Lavine, A.S. Chapter 9-Free Convection. In Fundamentals of Heat and Mass Transfer, 7th ed.; Ratts, L., Marchione, R., Eds.; John Wiley \& Sons: Hoboken, NJ, USA, 2017; pp. 593-652. 
29. ASHRAE. Chapter 16-Ventilation and infiltration. In ASHRAE Handbook: Fundamentals, SI ed.; ASHAE, Ed.; ASHRAE: Atlanta, GA, USA, 2017; pp. 415-453.

30. Natural Ventilation-WBDG_Whole Building Design Guide. Available online: https://www.wbdg.org/resources/naturalventilation (accessed on 11 January 2021).

31. Kalogirou, S.A. Chapter 9-Photovoltaic Systems. In Solar Energy Engineering_Processes and Systems, 2nd ed.; Kalogirou, S.A., Ed.; Academic Press: Oxford, UK, 2014; pp. 481-540. 